\title{
Ameliorating Impact of Phoenix dactylifera L. Leaves Oil Extract on Testicular Toxicity Induced by Gibberellic Acid: Histomorphometric and Immunohistochemical Studies
}

\section{Original Article}

\author{
Rania A. Ahmed ${ }^{1}$ and Amany E. Nofal ${ }^{2}$ \\ Department of Zoology, Faculty of Science, ' $S u e z$ University, Suez, ${ }^{2}$ Menoufia University, \\ Shebin El-Kom, Egypt
}

\begin{abstract}
Background: Gibberellic acid is an endogenous plant growth regulator, it has many toxic effects including testicular toxicity. Phoenix dactylifera L. (date palm) is widely used in traditional medicine as anticancer, hepatoprotective, neuroprotective, nephroprotective, gastrointestinal protective and antimicrobial agent.

Aim: The present work aimed to clarify the impact of Phoenix dactylifera L. leave oil extract on testicular toxicity induced by gibberellic acid in albino rats.

Materials and Methods: Five groups of rats were used. Group1: control, Group 2: corn oil group, Group 3: Phoenix dactylifera L. leaves oil extract group , Group 4: Gibberellic acid group .Group 5 : Phoenix dactylifera L. leaves oil extract and Gibberellic acid group. Histomorphometric, Histochemical, immunohistochemical and biochemical alterations were investigated in testicular tissue and serum.

Results: Gibberellic acid induced histopathological alterations, significantly decreased the Johnsen score of spermatogenesis, and significantly decreased the germ cell proliferation index (PI)., significantly decrease the epithelial height and tubular diameter and total glycogen content. Immuohistochemically, Gibberellic acid significantly decreased PCNA and GULT-3, while $\alpha$-SMA was significantly increased. Gibberellic acid decreased serum testosterone, progesterone and LH hormones and testicular antioxidants, and significantly increased testicular MDA. Treating rats with both Phoenix dactylifera L. leaves oil extract and Gibberellic acid ameliorated all histopathological morphometric, histochemical, immunohistochemical and biochemical alterations induced by Gibberellic acid.

Conclusion: Phoenix dactylifera L. leaves oil extract could ameliorate the histopathological and toxicological alterations induced by Gibberellic acid.
\end{abstract}

Received: 27 February 2020, Accepted: 13 May 2020

Key Words: $\alpha$-SMA, date palm, GULT-3, PCNA, spermatogenesis.

Corresponding Author: Rania Abd Elkarim Ahmed, Department of Zoology, Faculty of Science, Suez University, Suez, Egypt, Tel.: +20 1090232302, E-mail: rania.sheir@yahoo.com

ISSN: 1110-0559, Vol. 44, No.1

\section{INTRODUCTION}

Phytohormones or plant growth regulators (PGRs) are plant growth hormones that accelerate plant growth and are naturally produced by plants via biosynthesis or it may be applied to plants as chemical additives. Gibberellic acid (GA) is one of the six major classes of plant growth regulator hormones that is used extensively in many countries including Egypt to enhance the growth of many vegetables as (olive, tomatoes, pepper and cabbages) and fruits (such as grapes, melon, date palm and strawberries). As all PGRs, GA plays a significant role in improvement of many cellular processes and mechanisms during plant growth including cell division enhancement, stems and leaves elongation, stimulating flowering and fruiting, breaking dormancy, seed germination and sex expression ${ }^{[1-4]}$.

Individuals and animals may be vulnerable to residues of GA in diet containing vegetables and fruits treated with GA, or by drinking water contaminated with GA. Agricultural workers exposure to GA may occur via inhalation or by dermal contact at work places. However, several studies have reported that exposure to GA induces many hazards effects on individuals and animal health. GA was proven to induce oxidative stress and pathological alterations in many organs as spleen, testis, brain, lung, stomach and liver. Furthermore, GA has carcinogenic and genotoxic effects ${ }^{[1,2,4-7]}$.

Date palm (Phoenix dactylifera L.) belongs to the Arecaceae family, and is considered an important source of food in Middle East and North African countries. Good nutritional value of dates is based on its high content of certain nutrients such as carbohydrate, lipids, proteins, dietary fibers and essential minerals and vitamins ${ }^{[8,9]}$.

In traditional medicine different parts of date palm are widely used for the treatment of many disorders ${ }^{[10]}$. Numerous studies have proven the medicinal and nutritional benefits of Phoenix dactylifera L. Date fruits have been reported to possess immunostimulant, antioxidant, 
anti-fibrotic antimutagenic, nephroprotective, antibacterial, antifungal, anti-apoptotic, anti-tumoral, hepatoprotective, gastro-protective and neuro-protective effects ${ }^{[8,11,12]}$. The antioxidant activity of Phoenix dactylifera $L$. is attributed to the wide range of flavonoid content and phenolic compound including p-coumaric, ferulic, sinapic, gallic, catechin, chlorogenic, caffeic, coumaric, resorcinol, dactyliferic, p-hydroxybenzoic, vanillic, syringic, and isochlorogenic $\operatorname{acids}^{[8,13]}$.

The present work aims to clarify the impact of Phoenix dactylifera $L$. leaves oil extract on testicular toxicity induced by GA in albino rats.

\section{MATERIALS AND METHODS}

\section{Chemicals and plants used}

1- Gibberellic acid (GA): GA was obtained from El-Gomhoria Company for Trading Pharmaceutical Chemicals and Medical Appliances (Tanta, Egypt), as vials containing $1 \mathrm{gm}$ GA powder.

2- Phoenix dactylifera L. Leaves oil extract: Phoenix dactylifera $L$. fresh leaves were collected from Siwa Oasis; Egypt, washed in running tap water, cut into small pieces and dried for four week in room temperature, then blended to fine powder by a mechanical blender. Leave oil extraction was done by hexane and soxhlet apparatus according to Charef et al. ${ }^{[14]}$, and then the extract was dissolved in corn oil ${ }^{[9]}$

\section{Animals and treatments}

Fifty adult male Sprague Dawley rats weighing $185 \pm 15$ $\mathrm{g}$ were divided randomly into 5 groups in plastic cages (10 rats/ cage) as following: Control Group: Kept as control group; Corn oil group: Received corn oil orally/daily at dose of $0.1 \mathrm{ml} / 100 \mathrm{~g}$ for 4 weeks. PDOE group: Received Phoenix dactylifera L. leaves oil extract group; $250 \mathrm{mg} / \mathrm{kg}$ B.W orally/daily for 4 weeks ${ }^{[9]}$. GA group: Received GA $20 \mathrm{mg} / \mathrm{kg}$ orally daily for 4 weeks ${ }^{[15]}$. GA and PDOE group: Received both PDOE and GA for 4 weeks.

All animals were kept under standardized environmental conditions with free access to standard diet and water ad libitum throughout the whole experimental period. The study and all procedures were approved by the Animal Care and Bioethics Committee, Menoufia University, Egypt. (Approval No. MUFS /F/HI/ 3/ 19).

\section{Methods}

\section{Histopathological examinations}

At the end of the experiment, all rats were sacrificed by cervical dislocation, dissected and their right testes were removed, fixed in $10 \%$ neutral formalin, dehydrated, cleared and embedded in paraffin wax. Paraffin sections of 5 microns thickness from middle part of testis were prepared and stained with routine haematoxylin and eosin stain ${ }^{[16]}$.

\section{Spermatogenesis grading by Johnsen Score}

All testicular tissue sections were evaluated systematically and Spermatogenesis was graded from 1 to 10 according to Johnsen scoring system ${ }^{[17]}$.

\section{Histochemical Demonstration of General carbohydrates}

For histochemical purposes, sections of 5 microns thickness were cut, then general carbohydrates were demonstrated through Periodic acid-Schiff (PAS) stain ${ }^{[18]}$.

\section{Immunohistochemical Examination}

i. PCNA for spermatogenesis: Proliferating cell nuclear antigen (PCNA) were performed to indicate cell proliferation and for quantitative evaluation of spermatogenesis $^{[19]}$.

ii. Immunohistochemical demonstration of $\alpha$-SMA: For immunolocalization of alpha smooth muscle actin ( $\alpha$-SMA) in interstitial tissues, paraffin sections of 5 microns thickness were stained by avidin-biotin peroxidase method ${ }^{[20]}$.

iii. Glucose transporter membrane 3 (GluT-3): For immunohistochemical localization of GluT-3, 5-mm-thick sections were cut from paraffinembedded material. The tissue samples were treated with anti-GLUT-3 antibodies by performing the avidin-biotin immunohistochemical method ${ }^{[21]}$.

\section{5- Morphometric Evaluations and Image analysis}

i. To assess the diameters and germinal epithelial height of seminiferous tubules, images of histological slides of rights testicles were captured from the 10x objective lens, and then analyzed with ImageJ measurement software (NIH). Each of tubular diameters and epithelial heights were calculated by analysis of 10 randomly selected sections of the more circular cross-sections in each case and then , their average values were calculated.

ii. Digital images for stained slides with PAS, $\alpha$-SMA and GluT-3 were analyzed via semi-quantitative scoring system (Image J software, Java based application for analyzing images). The percentage of positive stained area (\%) was calculated as mean of 10 fields/ slide under high-power field $(\times 400)$ microscope.

iii. PCNA-Labeling Index (PCNA-LI): The PCNA-LI for each seminiferous tubule was estimated as a percentage of immuno-labeled cells to all basal cells. For each section, the mean $\pm \mathrm{SD}$ was calculated ${ }^{[22]}$.

\section{6- Biochemical Investigations}

i. Assessments of hormones values in the serum: For biochemical study, sera were obtained by centrifugation of the clotted blood samples and stored at $-20^{\circ} \mathrm{C}$ until used to determine each of ; Testosterone hormone ${ }^{[23]}$; Luteinizing hormone $(\mathrm{LH})^{[24]}$; and Progesterone hormone ${ }^{[25]}$.

ii. Assessments of antioxidant markers in Testicular tissue: For antioxidant demonstration, clear supernatants of testicular tissues were separated 
and used to assess each of the following parameters Malondialdhyde (MDA) ${ }^{[26]}$; Superoxide dismutase (SOD) activity ${ }^{[27]}$; 3- Catalase (CAT) activity ${ }^{[28]}$ and Glutathione peroxidase $(\mathrm{GPx})^{[29]}$.

\section{Statistical analysis}

Statistical analysis was performed for Spermatogenesis grading, morphometric and biochemical examinations using SPSS v.16. Results were articulated as mean \pm standard division (SD) and all statistical comparisons were analyzed by means of one-way ANOVA test followed by Post hoc analysis. A $P<0.01$ value was considered significant.

\section{RESULTS}

In the present results, Corn oil treated rats didn't show any alterations in all studies.

\section{1- Histopathological examination and} spermatogenesis Scoring by Johnsen system

(Figure 1 and Table 1), demonstrate the microscopic examination of testicular sections of control group and revealed normal structure with normal seminiferous tubules, interstitial tissue, Sertoli cells, and complete spermatogenesis. Histological evaluation of spermatogenesis via Johnsen score of control rats was $(9.26 \pm 0.49)$ as all seminiferous tubules were uniformed and contained the classical sequence of spermatogenic cells (spermatogonia, spermatocytes, spermatids and sperms) (Figure 1a, Table 2).

Animals treated with PDOE showed normal histoarchitecture of testicular tissue when compared with the controls, the testicular tissue showed the typical features of seminiferous tubules with normal spermatogenic cells, intertubular tissue and complete spermatogenesis having score $(9.74 \pm 0.38)$ (Figure $1 \mathrm{~b}$, Table 2). On the other hand, GA induced severs histopathological alterations in the testicular tissue; as degeneration, Pyknosis, blood vessels congestions, vaculation and haemorrhage. Separation of seminiferous tubules and degeneration of interstitial tissue were observed. The basal lamina showed marked thickening, some seminiferous tubules exhibited marked degree of shrinkage while the others were atrophied and devoid from germ cells (Figures 1c,1d,1e). Moreover, animals treated with GA showed significant decrease $(P<0.01)$ in Johnsen score $(3.12 \pm 1.47)$ when compared with control rats, as testicular tubules configuration, cellularity, and spermatic density were significantly reduced (Table 2). Johnsen scoring for this group exhibited various grades; such as score (1) where neither germ cells nor Sertoli cells were present, score(2) as there were Sertoli cells only but no germ cells present, score (3) as only spermatogonia were present, score (4) as only a few spermatocytes were present, score (5) as there were no spermatozoa or spermatids but many spermatocytes were present, score (6) where only few spermatids present and score (7) as no spermatozoa but many spermatids were present. However, Johnsen score grade 3 predominated (Figures 1c,1d,1e) (Table 2).
On the other hand, compared to testis sections of animals exposed to GA alone, animals treated with GA and PDOE showed marked improvement of testicular tissues, interstitial cells and testicular tubules configuration, cellularity, and spermatic density were within the normal appearance (Figure 1f). Histological assessment of spermatogenesis showed significant increase of Johnsen score $(P<0.01)$ into (7.31 \pm 0.56$)$ (Figure 1f, Table 2)

\section{2- Morphometric results}

Data obtained from image analysis denoted no significant statistical difference $(P<0.01)$ between the control group and PDOE treated animals. A significant decrease in the diameter and germ cell height of seminiferous tubules was recorded in testes of rats treated with GA when compared with the control group (Table 2). In comparison with the GA-treated animals, rats treated with GA and PDOE showed a significant increase in the mean of tubular diameter and in germinal epithelial height (Table 2).

\section{3- Histochemical Results of Glycogen content}

Microscopic examinations of testes sections of control rats and PDOE treated rats showed strong PAS-positive reactions with boundaries of the seminiferous tubules and head of sperms, moderate PAS-positive reactions in tunica albuginea and intertubular connective tissue, while spermatogenic cells were weakly stained. (Figures 2a, 2b; Table 3).

Testicular tissues of animals treated with GA exhibited an overall significant reduction $(P<0.01)$ of glycogen, with weak magenta coloration due to arrest of germinal epithelium and loss of sperms and thickened basal lamina of the seminiferous tubules, which exhibited moderate PAS reaction (Figure 2c; Table 3). Treating rats with both PDOE and GA induced a significant increase of glycogen content $(P<0.01)$ in testicular tissues when compared with GA-treated rats as glycogen appeared strongly in tunica albuginea as well as in the intertubular connective tissue, while spermatogenic cells exhibited weak reaction and the sperms heads showed strong reaction (Figure 2d; Table 3).

\section{Immunohistochemical results}

\section{i. Proliferative Cell Nuclear Antigen (PCNA)}

In the seminiferous epithelium, PCNA is expressed in the nuclei of spermatogonia. Examination of sections of both control and PDOE rats showed a positive reaction for PCNA (Figures 3a,2b), whereas animals treated with GA showed decreased expression of PCNA (Figure 3c). Animals treated with GA and PDOE showed an increase in the expression of PCNA in the spermatogonia (Figure 3d).

\section{PCNA-LI Results}

Results of PCNA expressing cells in all treatment groups are shown in table 3. Comparing PCNA-LI values of the PDOE treated group to that of the control group, showing 
no significant difference, while the values were significantly lower in the testes of GA treated group than those of the control group. On the other hand, animals treated with both GA and PDOE showed a significant improvement of the PCNA-LI values when compared with the corresponding testis of GA treated group.

\section{ii. immunohistochemical Scoring of $\alpha-S M A$}

Examination of sections of both control rats and PDOE rats, $\alpha$-SMA was detectable finely in the peritubular tissue that surround the seminiferous tubules and in blood vessels walls (figures $4 a, 4 b$, Table 3 ). Data obtained from image analysis of testes of rats treated with GA declared a statistically significant increase $(P<0.01)$ in mean $\%$ area of $\alpha$-SMA in the interstitial tissue and in the seminiferous peritubular boundary tissues (figure 4c, Table 3 ).

Rats treated with GA and PDOE declared a statistically significant reduction in mean $\%$ area of $\alpha$-SMA in the interstitial tissue and in the peritubular tissues when compared with GA treated group (Figure 4d, Table 3).

\section{iii- GLUT-3}

Microscopic Examination of animals from both control group and PDOE group showed a strong expression of GluT-3 in spermatogenic cells cytoplasm and membrane in all seminiferous tubules. GA induced significantly decrease $(P<0.01)$ in expression of GluT-3 in testicular tissues when compared with control group. On the other hand, animals treated with PDOE and GA showed significantly improvement $(P<0.01)$ of GluT-3 when compared with GA treated group (Figure 5, Table 3 ).

\section{Biochemical results}

\section{i. Changes in Testosterone, LH and Progesterone hormones}

Data shown in (Table 4) represented that there is no significant difference in values of in testosterone, LH and progesterone hormones between control and PDOE groups. Treating animals with GA caused significant reduction $(p<0.01)$ in testosterone, $\mathrm{LH}$, and progesterone levels when compared with control group. On the other hand, treating animals with both GA and PDOE induced significant increase $(p<0.01)$ of testosterone, $\mathrm{LH}$, and progesterone values when compared with GA treated group.

\section{ii. Oxidative stress markers in testicular tissue}

Data in (Table 4) showed that PDOE didn't cause any significant difference in oxidative stress markers in testicular tissue when compared to the control group. The activity of MDA in the GA -treated group was significantly $(P<0.01)$ increased. Treatment with PDOE and GA significantly reduced the level of MDA compared to the GA treated rats (Table 4). Treatment with GA caused significant reduction of CAT, SOD and GPx values $(P<0.01)$ when compared with control group. However on treatment with PDOE with GA, it was found to enhance CAT, SOD and GPx values significantly $(p<0.01)$ (Table 4$)$. 

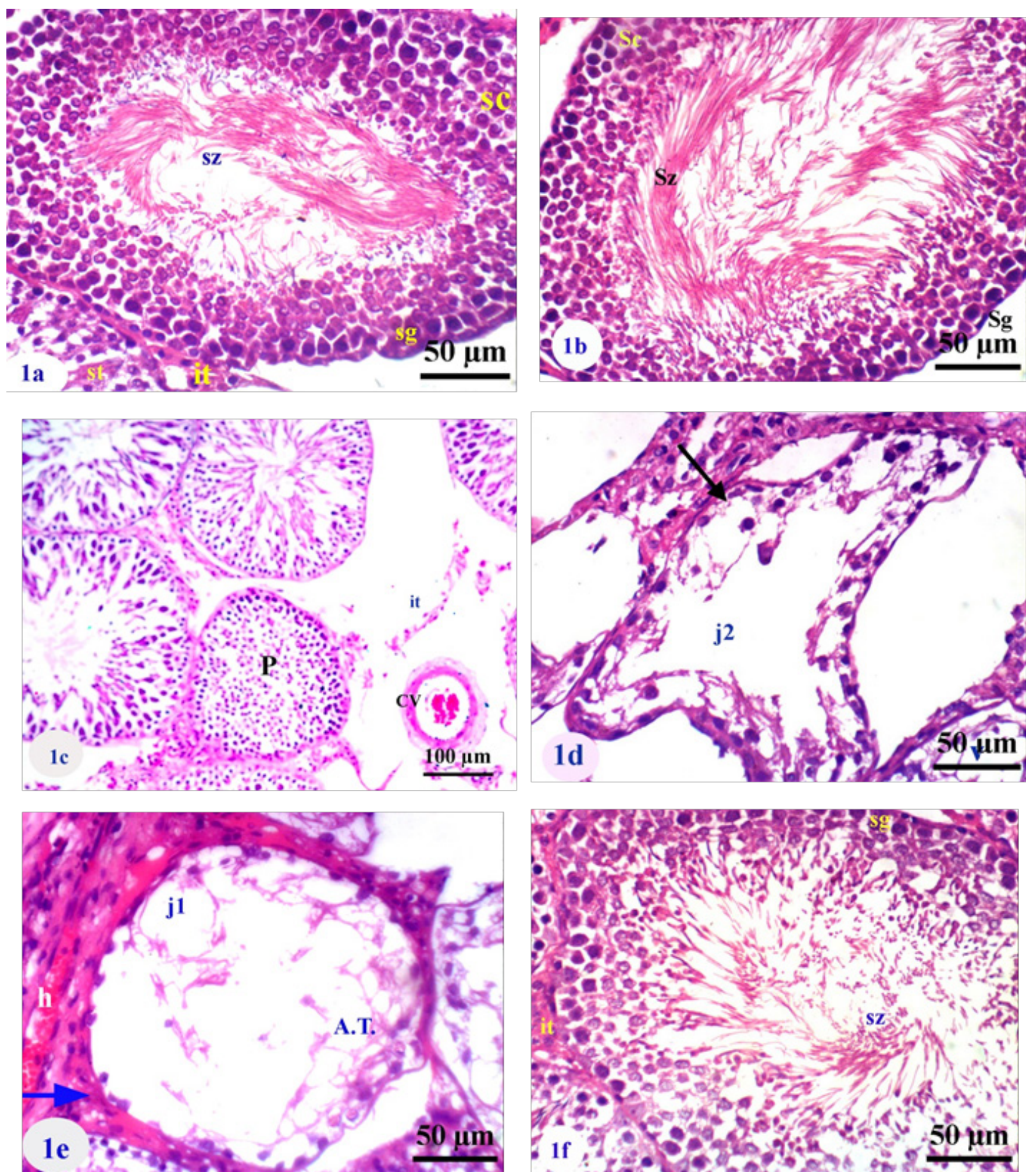

Fig. 1 : (a) Section in the testis of a control rat showing normal seminiferous tubules, sperms (Sz); spermatogonia (sg) interstitial tissue (it)., Sertoli cells (st), and spermatocytes (sc) (b) Section in testis of a rat treated with PDOE showing normal testicular architecture . (c) GA-treated rat showing, congested blood vessel (CV), Pyknosis (P) and degeneration of interstitial tissue (it).(d) GA-treated rat showing degenerated and shrinkaged tubule with Johnsen score grade $2(\mathrm{j} 2)$, vaculation (v) and detached germ layers (arrow) . (e) GA- treated rat showing atrophied tubules (A.T) with absence of all spermatogenic cells (j1), thickness of interstitial tissue (arrow) and haemorrhage (h).(f) Section of rat treated with both GA and PDOE showing normal seminiferous tubules with compact spermatogenic cells, and normal spermatogenesis. (H \& E stain, scale bar $50 \mu \mathrm{m} ; 1 \mathrm{c}$ : scale bar $100 \mu \mathrm{m}$ ). 

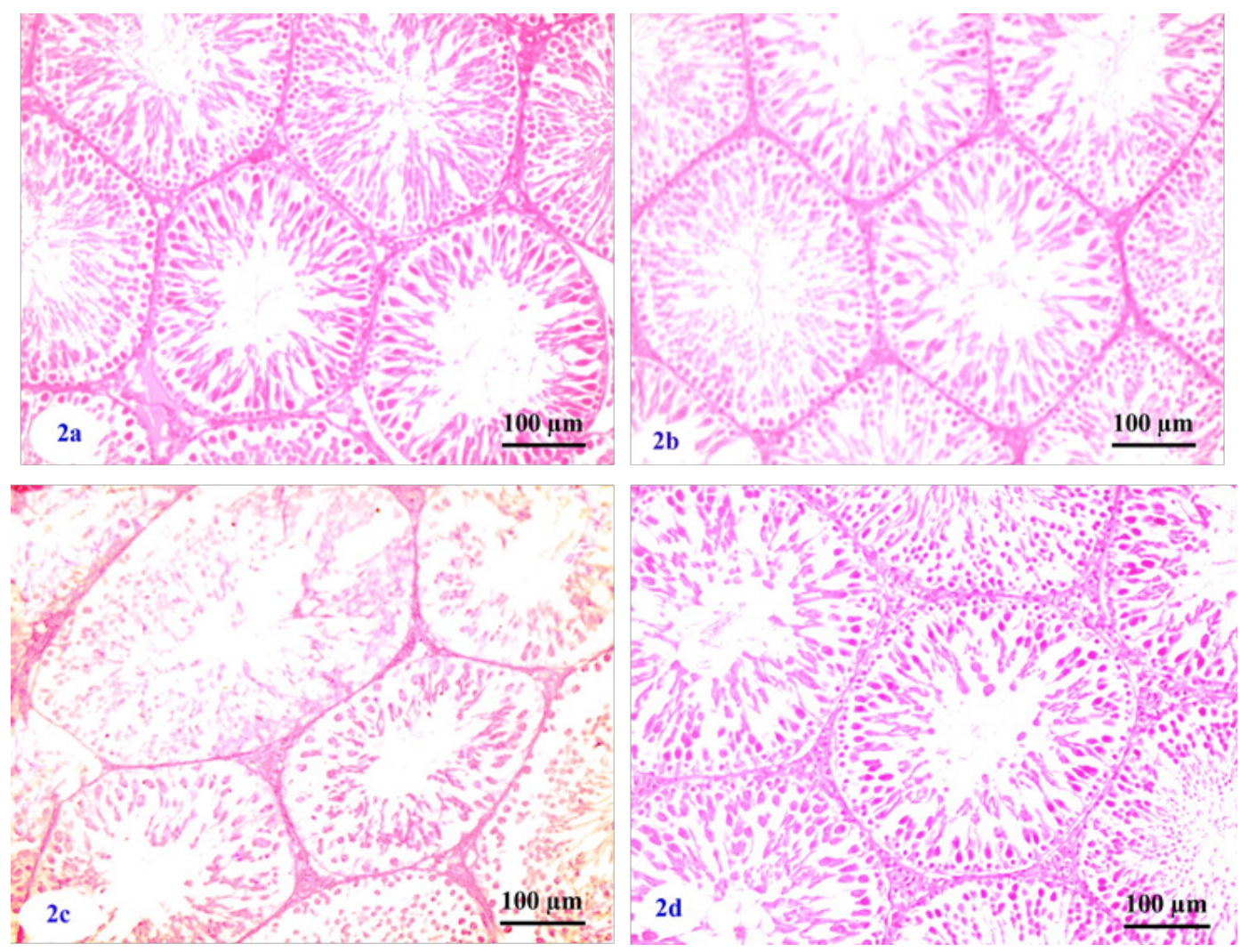

Fig. 2: (a) Section in a testis of a control rat showing a strong positive PAS reaction in tunica albuginea as well as in the intertubular connective tissue of testes. (b). PDOE treated rat showing normal distribution of PAS positive materials content. (c) Section in a testis of a rat treated with GA showing an overall significant reduction of PAS positive materials in seminiferous tubules. (d): Section of testis of a rat treated with both PDOE and GA showing an improvement of PAS positive materials content in testicular tissues (PAS stain; scale bar $100 \mu \mathrm{m}$ )

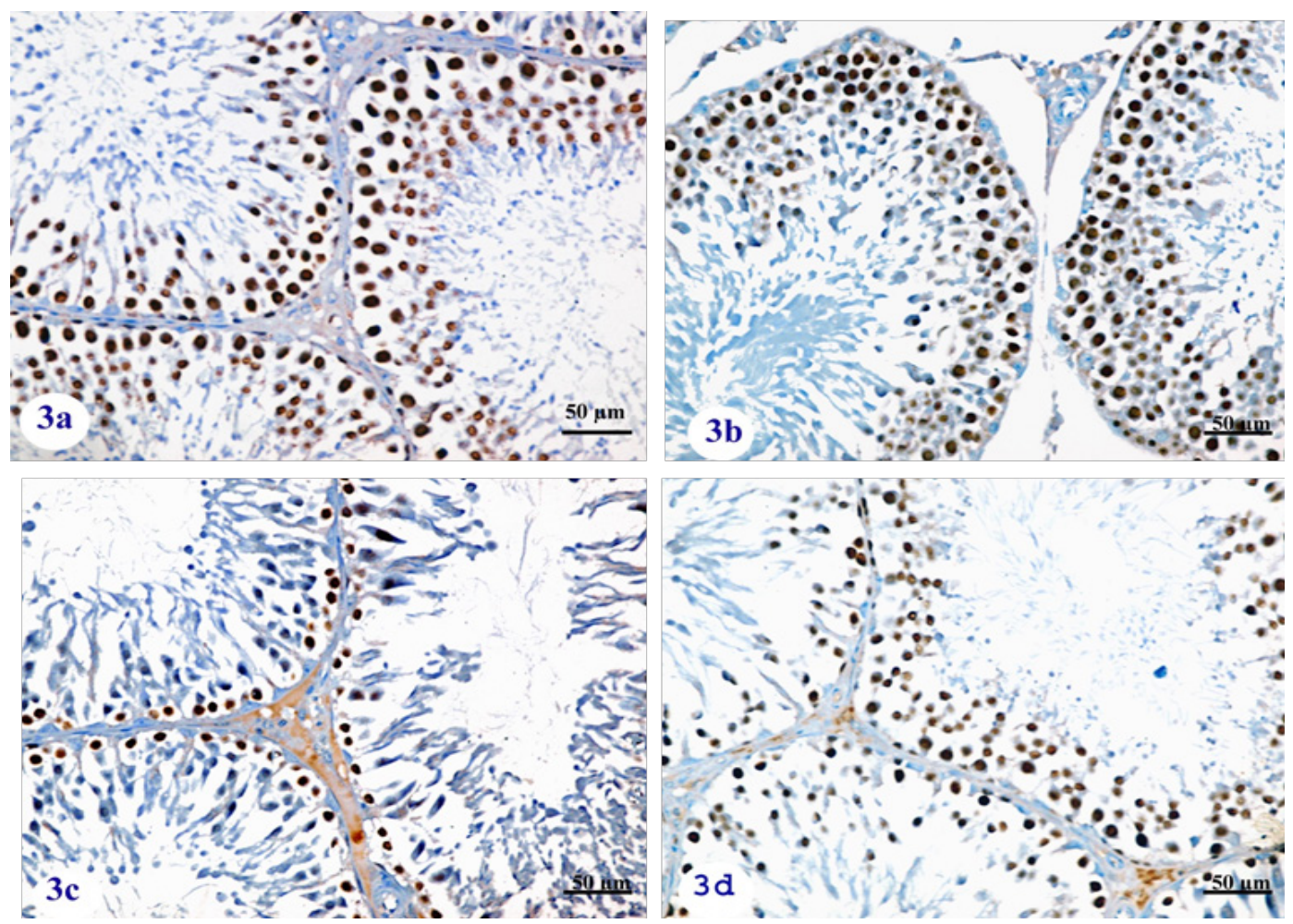

Fig. 3: (a) Section of control rat showing positive PCNA immunostaining reaction in the most of basal germ cells nuclei in the seminiferous tubules (brown colour) (b) Section in a testis of a rat treated with PDOE showing strong reaction of PCNA reaction in spermatogonia. (c): Weak expression of PCNA in spermatogonia of a rat treated with GA. (d) An increase in expression of PCNA in a rat treated with both GA and PDOE (PCNA immunostain ; scale bar 50 $\mu \mathrm{m})$ 

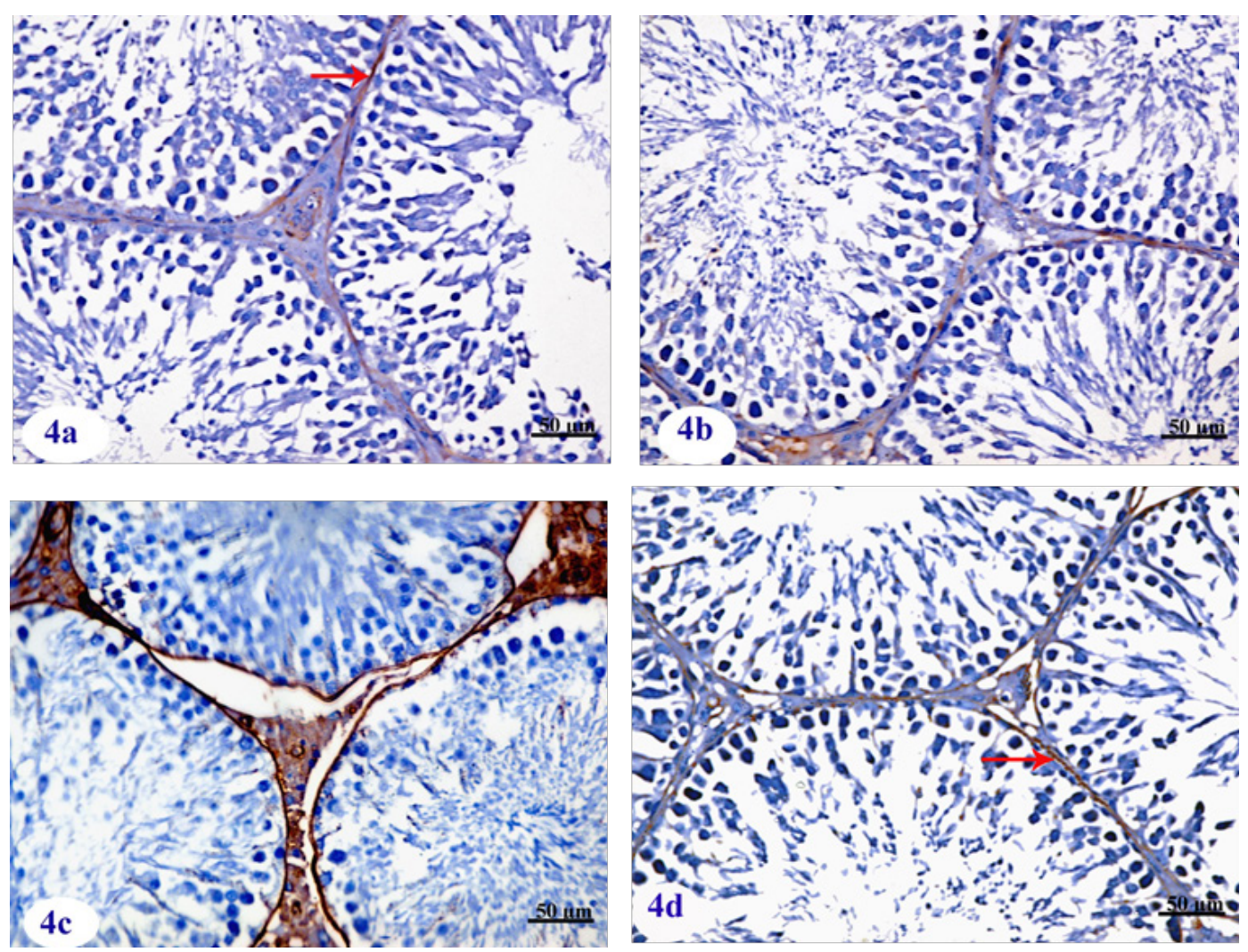

Fig. 4: (a) Section of a testis of a control rat showing positive $\alpha$-SMA immunostaining reaction in the peritubular tissue that surround the seminiferous tubules and in blood vessels walls (arrow) (b) Section of a testis of a rat treated with PDOE showing postive reaction of $\alpha$-SMA satin in interstitial tissue. (c): Section of a testis of a rat treated with GA declared a marked increase of $\alpha$-SMA expression in the interstitial tissue and in the seminiferous peritubular boundary tissues (d) Section of a testis of a rat treated with GA and PDOE declared a marked reduction of $\alpha$-SMA in the interstitial tissue and in the peritubular cells when compared with GA treated group ( $\alpha$-SMA immunostain ; scale bar $50 \mu \mathrm{m}$ ).
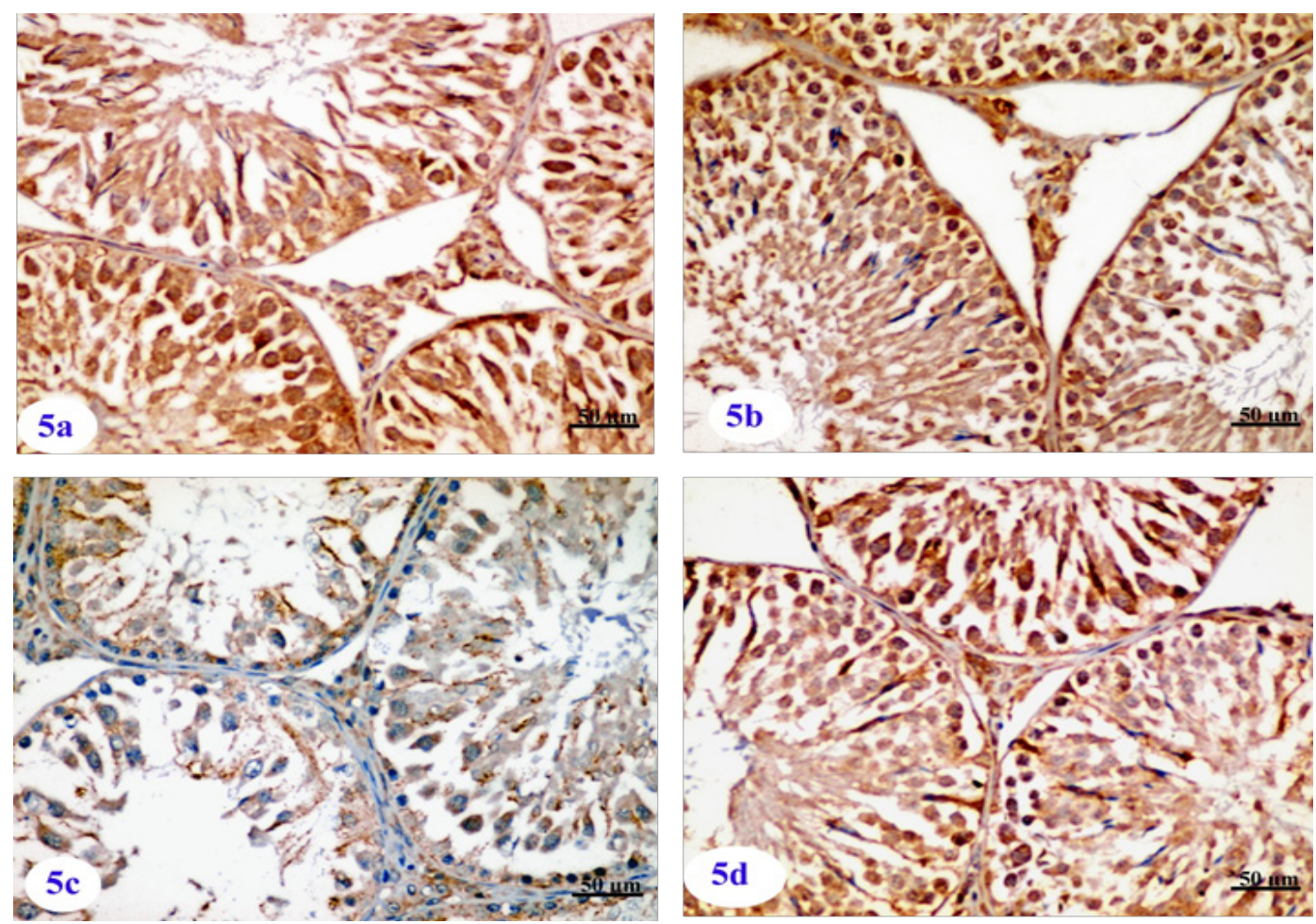

Fig. 5: (a) Section of a testis of a control rat showing a strong expression of GluT-3 in spermatogenic cells cytoplasm and membranes in all seminiferous tubules. (b) Section of a testis of a rat treated with PDOE showing strong reaction of GluT-3 in all spermatogenic cells. (c): Section of a testis of a rat treated with GA showing a weak expression of GluT-3 in spermatogenic cells. (d) An increase in expression of GluT-3 in a testicular tissue of a rat treated with both GA and PDOE (GluT-3 immunostain; scale bar $50 \mu \mathrm{m}$ ) 
Table 1: Histopathological Alterations in Testicular tissues in different groups (, , absent; + slight,++ mild; +++ , moderate; ++++ severe).

\begin{tabular}{lcccc}
\hline Alterations & Control & PDOE & GA & PDOE + GA \\
\hline Congested Blood Vessels & $\varnothing$ & $\varnothing$ & +++ & +++ \\
Pyknosis & + & + & + & +++ \\
Vaculations & + & $\varnothing$ & +++ & ++ \\
Tubular atrophy & $\varnothing$ & $\varnothing$ & ++ & ++ \\
Tubular separation & $\varnothing$ & $\varnothing$ & +++ \\
Interstitial Hemorrhage & $\varnothing$ & $\varnothing$ & ++ \\
Tubular degeneration & $\varnothing$ & & ++++ \\
\hline
\end{tabular}

Table 2: Changes in the Spermatogenesis Scoring System, and Morphometric alterations in different groups ( $\mathrm{n}=10, \mathrm{Mean} \pm \mathrm{SD}) ; P<0.01)$

\begin{tabular}{|c|c|c|c|}
\hline $\begin{array}{ll}\text { Groups } & \text { Parameters } \\
\end{array}$ & Johnsen Score & Diameter of seminiferous tubules $(\mu \mathrm{m})$ & Epithelial heights $(\mu \mathrm{m})$ \\
\hline Control & $9.26 \pm 0.49$ & $395.76 \pm 2.51$ & $129.19 \pm 1.84$ \\
\hline PDOE & $9.74 \pm 0.38$ & $398.21 \pm 4.23$ & $130.67 \pm 1.42$ \\
\hline GA & $3.12 \pm 1.47^{*}$ & $242.03 \pm 5.11^{*}$ & $70.32 \pm 1.55^{*}$ \\
\hline $\mathrm{PDOE}+\mathrm{GA}$ & $7.31 \pm 0.56^{* *}$ & $369.53 \pm 3.78^{* *}$ & $106.15 \pm 2.95^{* *}$ \\
\hline
\end{tabular}

Table 3: Means $\%$ area occupied in testis of Glycogen Content (\%), PCNA (\%), $\alpha$-SMA, GluT-3 in different groups ( $\mathrm{n}=10$, Mean \pm SD) ; $P<0.01$.

\begin{tabular}{llccc}
\hline Groups & Control & PDEO & GA \\
\hline Glycogen Content (\%) & $84.69 \pm 3.76$ & $86.82 \pm 2.39$ & $39.84 \pm 3.35^{*}$ & $72.94 \pm 4.22^{* *}$ \\
PCNA-LI & $89.66 \pm 3.44$ & $91.83 \pm 3.12$ & $38.50 \pm 3.83^{*}$ & $70.16 \pm 2.63^{* *}$ \\
$\alpha$-SMA & $1.64 \pm 0.27$ & $1.50 \pm 0.30$ & $12.68 \pm 1.76^{*}$ & $4.16 \pm 0.59^{* *}$ \\
GluT-3 & $66.35 \pm 3.58$ & $68.69 \pm 2.42$ & $33.44 \pm 3.91^{*}$ & $55.57 \pm 3.98^{* *}$ \\
\hline
\end{tabular}

Table 4: Alterations in serum hormones and testicular oxidative stress markers in different groups $(\mathrm{n}=10$, Mean $\pm \mathrm{SD},(p<0.01)$

\begin{tabular}{|c|c|c|c|c|}
\hline $\begin{array}{ll}\text { Alterations } & \text { Groups } \\
\end{array}$ & Control & PDOE & GA & PDOE + GA \\
\hline Serum Testosterone $(\mathrm{ng} / \mathrm{ml})$ & $2.59 \pm 0.14$ & $2.70 \pm 0.17$ & $1.11 \pm 0.09^{*}$ & $2.27 \pm 0.07^{* *}$ \\
\hline Serum $\mathrm{LH}(\mathrm{mIU} / \mathrm{ml}$ & $2.81 \pm 0.13$ & $2.84 \pm 0.12$ & $2.21 \pm 0.08^{*}$ & $2.52 \pm 0.10^{* *}$ \\
\hline Serum Progesterone (ng/ml) & $1.76 \pm 0.10$ & $1.83 \pm 0.11$ & $1.23 \pm 0.06^{*}$ & $1.62 \pm 0.14^{* *}$ \\
\hline Testicular MDA (nmol/g tissue) & $44.37 \pm 1.27$ & $42.87 \pm 1.86$ & $94.22 \pm 4.15^{*}$ & $48.68 \pm 1.46^{* *}$ \\
\hline Testicular SOD (U/g tissue) & $99.90 \pm 2.51$ & $101.48 \pm .63$ & $70.06 \pm 2.58^{*}$ & $90.34 \pm 1.32^{* *}$ \\
\hline Testicular CAT ( $\mu \mathrm{mol} / \mathrm{g}$ tissue $)$ & $1.91 \pm 0.10$ & $1.98 \pm 0.12$ & $1.08 \pm 0.29^{*}$ & $1.53 \pm 0.04^{* *}$ \\
\hline Testicular GPX (U/g tissue) & $146.83 \pm 3.03$ & $149.95 \pm 2.18$ & $93.16 \pm 5.38^{*}$ & $130.10 \pm 2.00^{* *}$ \\
\hline
\end{tabular}

\section{DISCUSSION}

In the present work, GA induced sever histopathological alterations in the testicular tissue as degeneration, pyknosis, blood vessel congestions, vaculation, haemorrhage, separation of seminiferous tubules, degeneration of interstitial tissue, marked thickness of basal lamina, some seminiferous tubules showed shrinkage while the others were atrophied and devoid of germ cells. Johnsen scoring system showed that GA induced a significant decrease of spermatogenesis. Morphometric results recorded a significant decrease in the tubular diameter and germ cells height in testes of rats treated with GA.

Our findings are in accordance with several studies that proved the histopathological alterations induced by gibberellic acid. GA resulted in damage of testicular cells, reduced testicular weight, induced a disturbance in the testicular architecture, disorganization of spermatogenic cells, widening of intercellular spaces as well as intertubular spaces, focal separation of germinal epithelium from the basement membrane, cytoplasmic vacuolation, pyknosis also exfoliation of spermatogenic cells into the tubules lumen $^{[5,15,30]}$.

Some studies demonstrated that GA caused morphometric alterations in testicles and disorders in spermatogenesis. GA caused a reduction in the size of seminiferous tubules, a significant decrease of both germinal epithelium height and the diameter of seminiferous tubules. Concerning spermatogenesis, GA induced hypospermatogenesis and 
a reduction in all stages of spermatogenesis, as well as a significant decrease in sperm count in the lumen of seminiferous tubules and epididymal sperm viability ${ }^{[1,5,30,31]}$ Previous studies have reported that testicular toxicity induces alterations in morphometric assessments and spermatogenesis. A significant reduction in the diameter and germ cell height of seminiferous tubules was recorded in testes of rats treated with tacrolimus when compared with the control rats ${ }^{[32]}$. Thiobencarb herbicide induced a significant reduction in the germinal epithelia height of seminiferous tubules in rats. Moreover, Johnsen scoring system indicated that thiobencarb resulted in a significant decrease of spermatogenesis as testicular tubules configuration, cellularity, and spermatic density were significantly decreased ${ }^{[33]}$. Currently, animals treated with GA and PDOE showed marked improvement of testicular tissues when compared with a rat treated with GA alone as most histopathological alterations induced by GA were completely ameliorated. Interstitial tissues and testicular tubules configuration, cellularity, orientation and spermatic density were within normal appearance. Moreover, histological assessment of spermatogenesis showed significant improvement of Johnsen score. Morphometrically, animals treated with GA and PDOE showed a significant increase in the mean of tubular diameter and in germinal epithelial height in comparison with the GA-treated animals.

To the best of our knowledge, the effects of date palm leaves on mammalian testis have not been previously reported, while some studied discussed the effect of date palm fruits, seeds and pollen on the testis. Some authors investigated the therapeutic effect of Date palm pollen extract (DPP) and Date palm seeds extract (DPS) on testicular damaged induced by cadmium $(\mathrm{Cd})$ and they reported that DPP and DPS restored all the testicular lesions induced by cadmium such as, degeneration, necrosis, cytoplasmic vaculation, pyknosis, atrophy and blood vessels congestion; in addition, DPP and DPS restored the normal testicular weight that was diminished by cadmium ${ }^{[34,35]}$. DPP succeeded in restoring the morphometric features of the germinal epithelium and the tubular diameter. Based on Johnsen's scoring system, co-administration of DPP plus Cd was significantly improved spermatogenesis in most of the spermatocytes (84\%) when compared with Cd-treated animals. Furthermore, DPP triggered germ cells to enter the late spermatids and maturation phases ${ }^{[34]}$. However, the sperm count, the sperm motility, the total number of sperm abnormalities (head and tail) were significantly improved after co-supplementation of DPP or DPS plus cadmium ${ }^{[34,35]}$.

Concerning histochemical results, GA caused a significant reduction $(P<0.01)$ of glycogen contents in the seminiferous tubules. On the other hand, treating rats with both PDOE and GA induced a significant increase of glycogen contents in testicular tissues when compared with GA-treated rats. GAinduced glycogen depletion was interpreted by many authors, who reported that treating rats with GA induced a reduction of total carbohydrates in liver and kidney ${ }^{[4,36]}$. Several studies discussed carbohydrates depletion on the testis, especially glycogen under different pathological conditions with the ameliorative effect of natural products.

Semicarbazide administration caused apparent weak PAS positive reaction in the testis along with a deposition of vacuolated homogenous PAS positive acidophilic materials between the seminiferous tubules ${ }^{[37]}$. Tramadol induced a marked reduction in PAS-positive materials in testicles ${ }^{[38,39]}$. Co-treatment of tramadol and vitamin $\mathrm{C}$ improved the PAS-positive materials content in seminiferous tubules and interstitial tissues ${ }^{[38]}$. El-hanbuli et al. ${ }^{[40]}$ reported that testosterone administration induced severe testicular damage with marked decrease of PAS +ve material, while In animals that received both silymarin and testosterone, the PAS positive material showed moderate staining affinity with normal distribution in the testicular tissues ${ }^{[40]}$.

Ultraviolet irradiation resulted in testicular damage and remarkable diminution of the mucopolysaccharide contents of testicular tissues. Curcumin intake along with UV irradiation preserved adequate testicular mucopolysaccharide content ${ }^{[41]}$. Vitamin E and Omega-3 intake succeeded in regenerating the glycogen content in rats testis against sever diminutions and disturbances caused by Acrylamide and Duloxetine respectively ${ }^{[2,43]}$.

This glycogen depletion was interpreted by many authors who attributed this phenomenon to the lost capacity of such damaged cells to metabolize glycogen properly and preserve its storage normally ${ }^{[44]}$. Feueret et al ${ }^{[45]}$ suggested that glycogen reduction may be resulted from the pathologically increased activities of lysosomal enzymes ${ }^{[45]}$. However, such suggestions could be considered as the reason of total carbohydrate depletion in testicles of GA-treated rats.

From immunohistochemical view; our findings showed that GA-treated animals revealed a significant decrease in expression of PCNA and PCNA-LI values when compared with control animals as an indicator of a depletion in the proliferation rate of spermatogenic cells and suggesting arrested spermatogenesis, while rats treated with both GA and PDOE showed an increase in the expression of PCNA in the spermatogonia and a significant improvement of the PCNA-LI values when compared with the corresponding testis of GA treated group.

Our findings coincide with Suriamurthy and Srikumar ${ }^{[5]}$ who reported that GA caused a significant reduction in testicular DNA content. Several studies have revealed that testicular damage is often accompanied by considerable reduction in PCNA expression and PCNA-LI values in spermatogenic cells, with reference to the therapeutic role of natural agents. Our previous studies have reported that Tacrolimus and Thiobencarb caused a reduction of cell proliferation in testicular tissues, as the number of PCNApositive cells was reduced remarkably; furthermore, the proliferative index (PI) was significantly decreased. Aged black garlic successfully improved the hazard effects of Tacrolimus as it increased cell proliferation rate and PCNALI values in the testis ${ }^{[32,33]}$. 
Duloxetine and fluoxetine induced highly significant decrease in number of positive PCNA immunostaining cells. Omega-3 uptake significantly improved numbers of positive PCNA immunostaining cells when compared to Duloxetine treated group ${ }^{[42,46]}$. Acrylamide induced a significant decrease in the surface area of PCNA immunoreactions; while testes of rats co-treated with acrylamide and coenzyme-Q showed an increase in expression of PCNA in the spermatogonia ${ }^{[47]}$. Cadmium induced a reduction in PCNA and Ki67 positive cells which improved significantly by Citrus sinensis peel extract $^{[48]}$. Fenthion pesticide caused significant reduction in PCNA-immunoreactivity. Curcumin administration to fenthion-treated rats revealed mild degenerative changes with partial improvement of active spermatogenesis ${ }^{[49]}$. El-Neweshy et al. ${ }^{[34]}$ suggested that the estradiol components of DPP play a critical effect in stimulating the regeneration of spermatogenic cells and testicular tissues that possess oestrogen receptors.

Concerning $\alpha$-SMA, data obtained from image analysis of the testis of rats treated with GA declared a statistically significant increase $(P<0.01)$ in mean $\%$ area of $\alpha$-SMA in the interstitial tissues and in the seminiferous peritubular boundary tissues. On the other hand, rats treated with GA and PDOE declared a statistically significant reduction in mean $\%$ area of $\alpha$-SMA in the interstitial tissues and in the peritubular tissues when compared with GA treated group.

In agreement, GA induced the deposition of hyaline homogeneous acidophilic material in the interstitial space ${ }^{[15]}$. Many testicular injuries are associated with progressive enlargement of lamina propria and interstitial tissue ${ }^{[50,51]}$. Irradiation, drugs, hormones and hypervitaminosis A induced the thickening of the lamina propria and interstitial tissue with spermatogenetic disturbance ${ }^{[51-53]}$. Generally, several investigators accepted the relation between the impaired spermatogenesis and the enlargement of lamina propria and interstitial tissue of the testis ${ }^{[54-59]}$.

In this context, Sato et al..$^{[59]}$ established an excellent nonlinear negative correlation between the mean thickness of the lamina propria score and the Johnsen's score of spermatogenesis. Furthermore, they indicated that the tubules with thin lamina propria is one of the best indicators of complete spermatogenesis ${ }^{[59]}$. Volkmann et al.$^{[60]}$ reported that increased thickened lamina propria that was shown by the highly expression of $\alpha$-SMA immunostain; associated with a marked disturbance in spermatogenesis score and decrease in PCNA immunostained cells count in testicular tissue. However, thickening of the lamina propria and decrease in spermatogenesis has resulted from increased oxidative damage and the impaired $\mathrm{O}_{2}$ transport ${ }^{[60]}$. DPP and DPS successfully reduced the thickened oedematous interstitial tissues that induced by $\mathrm{CdCl}_{2}^{[35]}$.

In the presented work; GA induced significantly decrease $(P<0.01)$ in expression of GluT-3 in testicular tissues when compared with the control group. On the other hand, animals treated with both PDOE and GA showed significant improvement $(P<0.01)$ of GluT-3 when compared with
GA the treated group. Our findings are in accordance with some reports which reported that GA administration markedly diminished the activities of both GGT and AST which indicated gluconeogenesis status critically in different tissues ${ }^{[5]}$. Glucose and fructose are principal energy sources for spermatogenic cells that provide the required energy for their proliferation, differentiation and motility via anaerobic glycolysis and fructose oxidation ${ }^{[61]}$. GA significantly decreased the fructose content in epididymis ${ }^{[2]}$. Hassan et al. ${ }^{[62]}$ correlated the reduction of fructose with the decreased testosterone, as testosterone influences the fructose synthesis by accessory sex organs and seminal vesicles. Moreover, decreased fructose content caused a decrease in the sperm count and quality ${ }^{[2]}$. Bisphenol A-induced testicular injury occurred through the reduction in insulin signalling and the impairment of glucose transport to the testis ${ }^{[63]}$. It was further shown that the abnormal glucose metabolism may cause defects in sperm development and diabetes was strongly associated with the abnormal spermatogenesis in human ${ }^{[64]}$.

GLUTs family of transporters plays a critical role in facilitating the passage of glucose via the cell membrane. GLUT-3 has been detected in the mouse, rat, and human testis $^{[64]}$. GLUT-3 is found in the midpiece of spermatozoa; where the oxidation process and glycolytic enzymes are mainly localized ${ }^{[61,64]}$. Farooqui et al. ${ }^{[65]}$ suggested that the degenerative changes in spermatogonia were associated with loss of Glut- 3 in abdominal testis. The LH-induced an increase in testosterone production was correlated with the changes in the expression of GLUTs, the rate of glucose uptake and metabolism during testicular activities. Thus, the increased expression of GLUT isoforms 3 and 8 and insulin receptor (IR) in the testis are responsible for the increase in serum testosterone level and the increased testicular expression of steroidogenic marker (StAR protein ${ }^{[64]}$. Covarrubias-Pinto et $a l^{[66]}$ indicated that oxidative stress and redox imbalance could induce an impaired GLUT3 localisation at the plasma membrane. Thus, the impact of PDOE on improvement of GLUT-3 content in testicular tissue may be due to its high antioxidant contents and free radical scavenging properties ${ }^{[9]}$.

The available biochemical results in this work indicated that treating animals with GA caused a significant reduction $(p<0.01)$ in serum testosterone, $\mathrm{LH}$, and progesterone levels when compared with the control group. While, treating animals with both $\mathrm{G}$ and PDOE induced a significant increase $(p<0.01)$ of testosterone level, LH, and progesterone values when compared with GA treated group. Our results are agreed with those of Hassan et al. ${ }^{[62]}$ who reported that plant growth regulators as GA significantly reduced the serum testosterone in rats, which were attributed to the direct testosterone-like action of GA, which inhibits testosterone secretion $^{[62]}$. Previous studies have reported that tacrolimus and thiobencarb induced reduction in testosterone, $\mathrm{LH}$, and progesterone $^{[32,33]}$.

Administration of DPP or DPS after $\mathrm{CdCl} 2$ succeeded to induce a significant improvement in level of sex hormones (testosterone, E2, FSH\& LH) ${ }^{[35]}$. However, El-Neweshy et $a l .^{[34]}$ attributed the therapeutic potency of DPP to 
its content of gonadotropin-like substances or steroidal components that acts as gonad-stimulating compounds, improving male fertility and maintaining normal serum levels of testosterone. Furthermore, this therapeutic effect may be due to the presence of flavonoids, steroids, saponins and estradiol compounds in DPP that have an effect on the hypothalamus pituitary axis, which increase the levels of sex hormones through raising the level of LH hormone, leading to stimulate secretion of gonadotropin releasing hormone $(\mathrm{GnRH})^{[35]}$.

Recently, GA induced oxidative stress, as the activity of MDA in the GA -treated group was significantly $(P<0.01)$ increased while CAT, SOD and GPx values were significantly reduced $(P<0.01)$ when compared with the control group. On the contrary, treatment with PDOE and GA significantly reduced the level of MDA compared to the GA treated rats. However co-treatment with PDOE and GA, enhanced CAT, SOD and GPx values significantly $(p<0.01)$.

In this context, several authors reported that GA administration induced an oxidative stress and generation of $\operatorname{ROS}^{[5,15,31,62,67,68]}$. In addition, GA caused a significant increase in testicular MDA content and a decrease in the activities of antioxidants such as SOD, CAT, GPx and GSH ${ }^{[5,31,62,68]}$. Bondy et al ${ }^{[69]}$ attributed the GA induced oxidative stress mechanism to the activation of microsomal mono-oxygenase which converts GA to reactive metabolites, then inducing cytochrome-P450 for the generation of ROS ${ }^{[69]}$. Excess GA administration that associated with the generation of ROS leads to peroxidation of the polyunsaturated fatty acids, which increased sperm plasma membrane permeability, leading to enzyme inactivation, DNA damage, and an oxidative destruction of cellular membranes and organelles, which in turn increases the production of toxic free radicals ending in cell death ${ }^{[5,15,31,67]}$.

Regarding the antioxidant activity of PDOE, the obtained results are in harmony with El-Neweshy et al. and El-Habibi et $a l .{ }^{[34,35]}$ who stated that DPP and DPS have antioxidant activities and reduced the cadmium induced oxidative stress in testis ${ }^{[34,35]}$. Palm date leaves was previously proven to contain potent antioxidants such as, tannins, steroid, phenolic, flavonoid, saponin, cumarin and trepenoid which have free radical scavenging properties ${ }^{[9,34,35,70]}$. The antioxidant role of palm date leaves may be due to its estradiol and flavonoids contents which have scavenging properties that is considered as the main important effects on the sperm quality. Flavinoids were recently reported to protect spermatogenic cells from oxidative damage caused by reproductive toxicants via blocking the generation of intracellular peroxide, decreasing DNA ladders and the formation of hypodiploid cells caused by $\mathrm{H}_{2} \mathrm{O}_{2}^{[71-73]}$. Estradiol compounds are a gonad stimulating substances that ameliorate male infertility and improve gonadotrophins activities ${ }^{[34,35]}$. The antioxidant role of phenolic compounds is due to their redox effects, which play a significant role in free radicals neutralizing and absorbing, also, peroxides decomposing ${ }^{[74]}$.
In the presented work, corn oil treated rats didn't show any pathological alterations either in testicular tissues nor in serum sex hormones during all studies that were proceeded; this finding was in accordance with Gad El-Hak and Mobarak $^{[75]}$, as they reported that corn oil didn't affect the normal histoarchitecture, testis weight, Sperm abnormality, serum Testosterone and LH hormones, and Testicular total antioxidants

\section{CONCLUSION}

GA caused a deleterious histological, morphometric, histochemical, immunohistochemical and biochemical alterations, with an impaired spermatogenesis and oxidative stress in testicular tissues. The findings of this study demonstrated that PDOE significantly ameliorated the reproductive toxicity induced by GA in rats which may be attributed to the antioxidant activities and free radical scavenging properties of PDOE. Furthermore, $\alpha$-SMA and Gult-3 can be recommended as an important indicator for spermatogenesis, however, more studies are required.

\section{CONFLICT OF INTERESTS}

There are no conflicts of interest.

\section{REFERENCES}

1. Ozturk H. B. , Erin N. and Balci M. K. Effect of Gibberellic Acid on the Levels of Tumor Necrosis Factor- $\alpha$, Interleukin-4 and Interleukin-10 in Rats. Turk J Endocrinol Metab 2019;23;150-157.

2. Alsemeh A. E., Moawad R.S. and Abdelfattah E. R. Histological and biochemical changes induced by gibberellic acid in the livers of pregnant albino rats and their offspring: ameliorative effect of Nigella sativa. Anatomical Science International. 2019; 94:307-323.

3. Abou-zeid N. A. and Abd-Ellah H.F. Neurotoxic Effects of Gibberellic Acid (GA3) and its Withdrawal in Adult Male Albino Rats: A Light and Electron Microscopic Study. Global Journal of Pharmacology. 2015 ; 9 (3): 222-233.

4. Sakr S. A. , Okdaha Y. A. and El-Abdb S F. Gibberellin A3 Induced Histological and Histochemical Alterations in the Liver of Albino Rats. ScienceAsia . 2003 ; 29 : 327-331.

5. Suriamurthy M. and Srikumar K. Effects of Plant Hormone Gibberellic Acid-3 on Rat Testicular Biomarkers and its Histology. World Journal of Pharmacy and Pharmaceutical Sciences. 2017; 6(9): 1276-1290.

6. Abdel Rahm M.A., Abdel Atty Y. H. ,Abdul Rahman M.M. , and Sabry M. Structural changes induced by gibberellic acid in the renal cortex of adult male albino rats. MOJ Anat Physiol. 2017;3(1):21-27. 
7. Hussein W.F., Farahat F. Y., Abass M. A. and Shehata A.S. Hepatotoxic Potential of Gibberellic Acid (GA3) in Adult Male Albino Rats. Life Science Journal, 2011;8(3) : 373-383.

8. Yusuf A.O., Buraimoh A. A., Agbon A. N., Raji K. B., Akpulu P. S. Preliminary Histological Studies on the Effect of Aqueous Fruit Extract of Phoenix dactylifera L. (Date Palm) on Lead Acetate-induced Cerebellar Damage in Wistar Rats . African Journal of Cellular Pathology. 2017 ; 8: 1-8 .

9. Al-zeiny S. M. and Abbas D. A. Comparative histological study of protective effect of oil and alcoholic extracts of dry palm dates and leaves (Phoenix dactylifera L) against CCL4 induced oxidative stress in rats. Kufa Journal For Veterinary Medical Sciences. 2017; 8 (1) : 79-89.

10. Awwad I. A. and Hussain S. M. Exploring the possible role of date fruit (Phoenix dactylifera, L) extract in amelioration of stroke in rats. Asian Journal of Biomedical and Pharmaceutical Sciences. $2015 ; 5(51): 31-35$.

11. Assirey E. A., Wagih H. M. And Mahran, H. N. Phoenix dactylifera L. Extract Diminished Apoptotic Effect in Cirrhotic Liver of a Rat Model. International Journal of Pharmacology. 2019; 15(1): 92-101.

12. Al-Qarawi A. A. , Abdel-Rahman H., Mousa H. M., Ali B. H., and El-Mougy S. A. Nephroprotective Action of Phoenix dactylifera in Gentamicin-InducedNephrotoxicity. Pharmaceutical Biology . 2008; 46( 4): 227-230.

13. El-Far A. H., Shaheen H. M., Abdel-Daim M. M. , Al Jaouni S. K. and Mousa S. A. Date Palm (Phoenix dactylifera): Protection and Remedy Food. Current Trends in Nutraceuticals. 2016 ;1(2) : 1-10.

14. Charef M., Yousfi M., Saidi M. And Stocker P.; Determination of the Fatty Acid Composition of Acorn (Quercus), Pistacia lentiscus Seeds Growing in Algeria, J Am Oil Chem Soc. 2008; 85. 921-924.

15. El-Beltagi E. M., Elwan, W. M. , El-Bakry, N. A., Salah E.F. Histological and immunohistochemical study on the effect of gibberellic acid on the seminiferous tubules of testis of adult albino rat and the possible protective role of grape seeds proanthocyanidin extract. Tanta Medical Journal. 2017; 45:79-91.

16. Drury, R. A. and Wallington, E. A. Carleton's Histological Technique., 1980 ; 5th Edition, Oxford University Press, New York. .p. 362.

17. Johnsen SG: Testicular biopsy score count - a method for registration of spermatogenesis in human testis: normal values and results in 325 hypogonadal males. Hormones, 1970; 1: 1-24.
18. Hotchkiss, R.D. (1948): A microchemical reaction resulting in the staining of polysaccharide structures in fixed tissue preparations. Arch Biochem.; 16: 131.

19. Eldridge, S.R. and Goldsworthy, S.M. Cell proliferation rates in common cancer target tissues of B6C3F1 mice and F344 rats: effects of age, gender, and choice of marker. Fundam Appl Toxicol. 1996; 32: 159- 167.

20. Abdel-Dayem M.M. Histological and Immunohistochemical Changes in the Adult Rat Testes after Left Experimental Varicocele and Possible Protective Effects of Resveratrol. Egypt. J. Histol., 2009; 32(1): 81 - 90.

21. Essawy ,T. A. and Hakam , H. M . The expression of alpha-smooth muscle actin [ $\alpha$-SMA] in posterior lingual glands in normal and diabetic rats. C.D.J. 2009 ; 25 (2): 149-157.

22. Younes M, Lechago LV, Somoano JR, Mosharaf M, Lechago J. Immunohistochemical detection of Glut3 in human tumors and normal tissues. Anticancer Res. 1997;17(4A):2747-2750.

23. Sizonenko, P. C. Normal sexual maturation Pediatrician, 1987; 14(4): 191-201.

24. Kosasa, T. S. Measurement of human chorionic gonadotropin. J Reprod Med; 1981; 26(4): 201-206.

25. Edward WV, Sharon DK, Marc RP, William B, Kathy $\mathrm{C}$, et al. $17 \mathrm{OH}$ Progesterone Blunts the Hypertensive Response Associated with Reductions in Uterine Perfusion Pressure in Pregnant Rats. Am J Obstet Gynecol. 2009. 201: 324e1-324e6.

26. Ohkawa H, Ohishi N, Yagi K. Assay for lipid peroxidase in animal tissue by thiobaubituric acid reaction. Anal Biochem. $1979 ; 95: 351-358$.

27. Rest R.F, Spitznagel, JK. Subcellular distribution of superoxide dismutases in human neutrophils. Influence of myeloperoxide measurement of superoxide dismutase activity. Biochem.J. 1977; 166(2):145-153.

28. Aebi H, Wyss SR, Scherz, B, Skvaril, F. Heterogeneity of erythrocyte catalase II. Isolation and characterization of normal and variant erythrocyte Catalase and their subunits. Eur.J.Biochem 1974 ; 48(1): 137-145.

29. Rotruck, JT, Pope AL, Ganther, HE, Swanson AB., Hafeman DG, Hoekstra WG. Selenium: Biochemical roles as a component of glutathione peroxidase, Science. 1973; 179: 588 - 590 .

30. El-mofty MM, Sakr SA. Introduction of neoplasms in the Egyptian Toad by gibberellin A3. Oncology, 1988; 45: 61-64.

31. Farahat FY, Ibrahim NA, Elkhateeb SA, and Shehata AS. Sub-Chronic Effects of Gibberellic 
Acid Repeated Exposure on the Testis of Adult Albino Rats (Biochemical, Histopathological and Immunohistochemical Study). Ain Shams Journal of Forensic Medicine and Clinical Toxicology. 2013; 20:106-115.

32. Ahmed RA, Nofal AE, El-massady FA. Effect of Aged Black Garlic on Reproductive Toxicity induced by Tacrolimus in Male Rats: Histological and Immunohistochemical studies. Transylvanian Review , 2017 ; 25 (20) : 5059-5066.

33. Ahmed RA. Thiobencarb decreases testicular germ cell proliferation, inhibits spermatogenesis and increases apoptosis: histological and immunohistochemical assessments. ejpmr, 2017,4(10) : 16-22.

34. El-Neweshy M. S., El-Maddawy Z. K. \& El-Sayed Y. S. Therapeutic effects of date palm (Phoenix dactylifera L.) pollen extract on cadmium-induced testicular toxicity. Andrologia. 2013 ;45(6):369-78.

35. El-Habibi EM. ; El-Komy MM. and Saad HO. Protective Effect of Date Palm Extracts on Cadmium-Induced Infertility in Male Rats. The Egyptian Journal of Hospital Medicine. 2017; 69 (4) : 2181-2190.

36. Sakr SA, El-Messedy FA and Abdel-Samei HA. Histopathological and histochemical effects of gibberellin A3 on the kidney of albino rats. J Egypt Germ Soc Zool. 2002 ; 38,1- 10.

37. Mansour AM, Ibrahim MA, Laag EM and Zamzam AF. Histological Study of the Effect of Semicarbazide on Testicular Seminiferous Tubules of Juvenile Albino Rat. Ain Shams Journal of Forensic Medicine and Clinical Toxicology. 2018; 30: 27-37.

38. Soliman ME, Atteya SE, Ghobashy HA., Noya DA. Mahmoud RA. The effect of tramadol on seminiferous epithelium of albino rats and the protective effect of vitamin C. Menoufia Medical Journal . 2017; 30:1125-1134.

39. Abou Elnaga AA, Kassab AA, Soliman GM, El Shal AO. Histological and immunohistochemical study of the effect of tramadol on the seminiferous tubules of adult albino rat and the effect of its withdrawal. Tanta Medical Journal. 2018; 46:38-53.

40. El-hanbuli HM. , Abo-sief AF. and Mostafa T. Protective effect of silymarin on the testes of rats treated with anabolic androgenic steroid: A biochemical, histological, histochemical and immunohistochemical study. Journal of Histology \& Histopathology . 2017; 4(10): 1-7.

41. Sharaf HA, Morsy FA, Shaffie NM and El-Shennawy AT. Histological and Histochemical Study on the Protective Effect of Curcumin on
Ultraviolet Irradiation Induced Testicular Damage in Albino Rats. J Cytol Histol. 2012 ; 3(6) : 1-8.

42. Badr El- Din S. and. Abd-El Aty O. Biochemical and immunocytochemical studies of the testicular changes after treatment with duloxetine hydrochloride and the possible protective effects of omega 3 in adult rat model of depression. AAMJ. $2012 ; 10(3): 264-300$.

43. Hasanin NA., Sayed NM, Ghoneim FM, Al-Sherief SA. Histological and Ultrastructure Study of the Testes of Acrylamide Exposed Adult Male Albino Rat and Evaluation of the Possible Protective Effect of Vitamin E Intake. J Microsc Ultrastruct. 2018;6(1):23-34.

44. Orr TW, Price DE and Stickland LH . The glycogen content of rats liver poisoning with large doses of pdimethyl amino azobenzene. J Pathol Bacter. $1948 ; 60,573-81$.

45. Feuer G, Goldbery L and Gilson K . Liver response tests. VII. Coumarin metabolism in relation to the inhibition of rat liver glucose. 6-phosphatase. Fd Cosmet Toxicol. (1966); 4, 157.

46. Soliman ME, Mahmoud BL, Kefafy MA, Yassien RI, El-Roghy ES. Effect of antidepressant drug (fluoxetine) on the testes of adult male albino rats and the possible protective role of omega- 3 . Menoufia Medical Journal. 2017, 30:1135-1142.

47. Mazen NF. and Elnegris HM. Role of coenzyme Q10 in testicular damage induced by acrylamide in weaned albino rats: a histological and immunohistochemical study. The Egyptian Journal of Histology. 2013 ; 36:164-174.

48. Akunna G, Obikili E., Anyanwu E., Esom E. Protective and curative role of Citrus sinensis peel on cadmium-induced testicular and spermatic damage: a morphometric and immunohistochemical evaluation using monoclonal antibodies against Ki-67 and proliferating cell nuclear antigen. Eur. J. Anat. 2017 ; 21 (1): 19-30.

49. Othman AI and Abdel-Hamid M. Curcumin Mitigates Fenthion-Induced Testicular Toxicity in Rats: Histopathological and Immunohistochemical Study. African Zoology. 2017 ; 52(4), 209-215.

50. Soderstrom KO. Tubular hyalinization in human testis. Andrologia. 1986;18:97-103.

51. Ahmed RA.. Histological Assessment and Quantification of Hypervitaminosis A-induced Fibrosis in Liver, Kidney and Testis of Albino Rats. World J Pharm Sci 2017; 5(8): 209-220.

52. Wong TW, Straus FH, Warner NE. Testicular biopsy in the study of male infertility. I. Testicular causes of infertility. Arch Pathol 1973; 95:151-9. 
53. Almasry SM. , Hassan ZA, Elsaed WM. , Elbastawisy YM. Structural evaluation of the peritubular sheath of rat's testes after administration of ribavirin: A possible impact on the testicular function. International Journal of Immunopathology and Pharmacology . 2017; Vol. 30(3) 282-296.

54. Santamaria L, Martin R, Nistal M, Paniagua R. The peritubular myoid cells in the testes from men with varicocele: an ultrastructural, immunohistochemical and quantitative study. Histopathology 1992;21: 423-33.

55. Paniagua R, Martinez-Onsurbe $P$, Santamaria L, Saez FJ, Amat P, Nistal M. Quantitative and ultrastructural alterations in the lamina propria and Sertoli cells in human cryptorchid testes. Int J Androl. 1990;13:470-87.

56. Pesce C, Reale A. Correlation of morphological variables in germ-cell hypoplasia. Arch Androl 1987;19:1-4.

57. Luetjens CM, Gromoll J, Engelhardt $\mathrm{M}$, von Eckardstein S, Bergmann N, Nieschlag E, et al. Manifestation of Y-chromosomal deletions in the human testis: a morphometrical and immunohistochemical evaluation. Hum Reprod 2002;17:2258-66.

58. Gulkesen KH, Endogru T, Sargin CF, Karpuzoglu G. Expression of extracellular matrix proteins and vimentin in testes of azoospermic men: an immunohistochemical and morphometric study. Asian J Androl. 2002;4:55-60.

59. Sato Y1, Nozawa S, Iwamoto T. Study of spermatogenesis and thickening of lamina propria in the human seminiferous tubules. Fertil Steril. 2008; 90(4):1310-2.

60. Volkmann, J, Muller, D, Feuerstacke, C. (2011) Disturbed spermatogenesis associated with thickened lamina propria of seminiferous tubules is not caused by dedifferentiation of myofibroblasts. Human Reproduction 26(6): 1450-1461.

61. Roya VK, Krishnab A. The expression pattern of the glucose transporter GLUT-5 in the testis during the spermatogenic cycle of the vespertilionid bat Scotophilus heathi. General and Comparative Endocrinology .2013 ; 191: 59-64.

62. Hassan HA., Isa AM., El-Kholy WM, Nour SE. Testicular disorders induced by plant growth regulators: cellularprotection with proanthocyanidins grape seeds extract. Cytotechnology. 2013; 65: 851-862.

63. D'Cruz SC, Jubendradass R, Mathur PP. Bisphenol A induces oxidative stress and decreases levels of insulin receptor substrate 2 and glucose transporter 8 in rat testis. Reprod Sci. 2012 ; 19:163-172.
64. Banerjee A., Anuradha, Mukherjee K., and Krishna A. Testicular Glucose and Its Transporter GLUT 8 as a Marker of Age-Dependent Variation and Its Role in Steroidogenesis in Mice. J. Exp. Zool. 2014; 321A : 490-502.

65. Farooqui SM, Al-Bagdadi F, O'Donnell JM, Stout R. Degenerative changes in spermatogonia are associated with loss of glucose transporter (Glut 3) in abdominal testis of surgically induced unilateral cryptorchidism in rats. Biochem Biophys Res Commun. 1997 ;236(2):407-12.

66. Covarrubias-Pinto A, Moll P, Solís-Maldonado M, Acuña AI, Riveros A, Miró MP, Papic E, Beltrán FA, Cepeda C, Concha II, Brauchi S, Castro MA. Beyond the redox imbalance: Oxidative stress contributes to an impaired GLUT3 modulation in Huntington's disease. Free Radic Biol Med. 2015;89:1085-1096.

67. Soliman HA, Mantawy MM, Hassan HM. Biochemical and molecular profiles of gibberellic acid exposed albino rats. J Am Sci 2010; 6:224-229.

68. Premalatha R., Jubendradass R., Srikumar K \& Mathur P. Gibberellic acid acts as an agonist of steroidogenesis in male rats. Andrologia 2014, 46, 902-909.

69. Bondy SC, Naderi S. Contribution of hepatic cytochrome P450 systems to the generation of reactive oxygen species. Biochem Pharamacol, 1994; 48: 155-159.

70. Kriaa W. , Fetoui H. , Makni M., Zeghal N. , Drira N. Phenolic Contents and Antioxidant Activities of Date Palm (Phoenix dactylifera L.) Leaves, International Journal of Food Properties. 2012 ; 15(6) : 1220-1232.

71. Chow JM, Shen SC, Huan SK, Lin HY, Chen YC . Quercetin, but not rutin and quercitrin, prevention of $\mathrm{H}_{2} \mathrm{O}_{2}$-induced apoptosis via anti-oxidant activity and heme oxygenase 1 gene expression in macrophages. Biochem Pharmacol. 2005 ; 69:1839-1851.

72. Kalender Y, Kaya S, Durak D, Uzun FG, Demir F . Protective effects of catechin and quercetin on antioxidant status, lipid peroxidation and testis-histoarchitecture induced by chlorpyrifos in male rats. Environ Toxicol. Pharmacol. 2012; 33:141-148.

73. Mi Y, Zhang C, Li C, Taneda S, Watanabe G, Suzuki AK, , Taya K. Quercetin attenuates oxidative damage induced by treatment of embryonic chicken spermatogonial cells with 4-nitro-3-phenylphenol in diesel exhaust particles. Biosci Biotechnol Biochem. 2010; 74:934-938

74. Shahidi F, Janitha PK and Wanasundara PD. Phenolic antioxidants. Critical Reviews of Food Science \& Nutrition. 1992 ; 32(1),67-103. 
75. Gad El-Hak HN and Mobarak YM. Copper oxychloride-induced testicular damage of adult albino rats and the possible role of curcumin in healing the damage. Environmental Science and Pollution Research volume. $2020 ; 27$, pages11649-11662. 


\section{الملخص العربى}

\section{التأثير المُحسيّن لمستخلص أوراق النخيل على سمية الخصية الناجمة عن حمض الجبريليك : دراسات نسيجية قياسية و كيمياء نسيج مناعية أفية \\ رانيا عبد الكريم ابراهيم أحمد' وأماني إبراهيم نوفلَ هله}

' قسم علم الحيوان ـ كلية العلوم - جامعة السويس

بقسم علم الحيوان ـ كلية العلوم - جامعة المنوفية

مقدمة: حمض الجبريليك من الهرمونات النباتية وله العديد من الآثار السامة بما في ذلك سمية الخصية. يستخدم تمر النخيل على نطاق و اسع في الطب الشعبي كمضاد للسرطان، كذللك للوقاية من امر اض الكبد، الكلى و الاعصاب وكذلك يستخدم كمضاد للميكروبات.

الهدف: تهدف الدر اسة إلى استيضاح تأثثر مستخلص أوراق النخيل على سمية الخصية الناجم عن حمض الجبريليك في ذكور الجرذان البيضاء. المواد والطُرق: تم استخدام خمسه مجموعات من ذكور الجرذان البيضاء. المجموعة الاولى: المجموعة الضابطة، المجمو عة الثانية: أعطيت جرذان هذه المجمو عةزيت الذرة، المجمو عة الثالثة: أعطيت جرذان تلك المجمو عة المستخلص الزيتي لأور اق النخيل، المجموعة الر ابعة: تمت معاملة تلك المجموعة بحمض الجبريليك، المجموعة الخامسة: تمت معاملتها بكلٍ من حمض الجبريليك وأوراق النخيل. تم در اسه التغيرات النسيجية و المورفومترية و الكيمياء نسيجية

$$
\text { و الكيمياء نسيج مناعية و الكيموحيوية علي أنسجة الخصية و السيروم. }
$$

النتائج: اظهرت النتائج ان حمض الجبريليك يسبب عديد من التغيرات الهستوباثولوجية، وكذلك انخفاض ملحوظ في كلا من: مر احل تكوين الحيو انات المنوية، قُطر الانابيب المنوية، ارتفاع طبقة الخلايا الجرثومية اظهرت النتائج النسيج كيميائية ان محتوي الجليكوجين قد انخفض بشكل ملحوظ في المجموعة المعالجة بحمض الجبريلك. كما اظهرت النتائج الكيمياء نسيج مناعية ان حمض الجبريليك ادى الى انخفاض كبير في معدل التعبير عن PCNA و و التعبير عن-SMA بشكل ملحوظ. ادى حمض الجبريليك لنقص هرمون التستوستيرون و هرمون البروجسترون و هرمون LH وكذلك إنخفاض مستوي مضادات الأكسدة وزيادة MDA في أنسجة الخصية. أظهرت النتائج ان معاملة الجرذان بأور اق النخيل ادى الى تحسين جميع التغير ات النسيجية و المورفومثريه و الكيمياء نسيج مناعية و الكيموحيوية الناجمة عن حمض الجبريليك بشكل ملحوظ. الخلاصة: يمكن لاور اق نخيل التمر ان تقي الخصية من السمية الناجمة عن حمض الجبرليك بسبب خصائصها المضادة 